\title{
COMPETITIVENESS LEVEL OF THE AIRLINE INDUSTRY: A SCALE DEVELOPMENT STUDY
}

\author{
Ferhan Sengur ${ }^{1}$, Temel Caner Ustaomer ${ }^{2}$ \\ 1,2 Faculty of Aeronautics and Astronautics, Eskisehir Technical University, Eskisehir, Turkey
}

Received 1 November 2018; accepted 17 January 2019

\begin{abstract}
In this study, it was aimed to develop a scale to determine the international competitiveness level of the airline industry. 36 items in the survey were applied on 181 airline managers, aviation experts and academics. At the end of the study, a scale consisting of 25 items describing $62.973 \%$ of the total variance was obtained. The exploratory factor analysis showed that the scale consisted of five sub-dimensions called government, firm strategy, structure and rivalry, demand conditions, related and support industries and factor conditions. As a result of confirmatory factor analysis, five-dimensional model was determined to be appropriate $\left(\chi^{2}=366.936 ; \mathrm{df}=262 ; \mathrm{p}=0.00 ; \chi^{2} / \mathrm{df}=1.401 ; \mathrm{RMSEA}=0.047 ; \mathrm{CFI}=.951\right.$; $\mathrm{GFI}=.862$ ).
\end{abstract}

Keywords: airline industry, scale development, Diamond model, industry competitiveness, competitiveness analysis.

\section{Introduction}

Airlines are an important part of the air transport system. Moreover, airlines have strategic importance because they link the regions they serve. In terms of geographical location, Turkey is positioned as a transit point between Asia, Europe and the Middle East. The bilateral agreements and the liberal policies have transformed this geographical area into an important center for passenger transport. Therefore, it is essential to understand the development dynamics of the airline industry. In this study, firstly, the literature review related to diamond model will be given, and then Porter's diamond model will be explained in details. In the findings part, explanatory and confirmatory factor analyzes of the scale will be presented. In the conclusion section, the results of the explanatory and confirmatory factor analysis of the scale will be discussed.

\section{Literature Review}

There are many studies on international competitiveness. Öz (1999) applied Porter's diamond framework to Turkish glass, leather clothes, construction, flat steel and automobiles industries. Her findings were generally supportive of Porter, meaning that the diamond framework works in a developing country setting. Bulu et al. (2006, 2007 and 2008) analysed the competitiveness level of Turkish electronic sector, Turkish food industry and tourism sector in Bolu region by using Porter's diamond model. Their research revealed that the international competitiveness level of these industries were determined as medium

${ }^{2}$ Corresponding author: temelcanerustaomer@anadolu.edu.tr 
level. Erarslan et al. (2007, 2008 and 2009) conducted Porter's diamond model to analyse the competitiveness level of Turkish plastic sector, Turkish marble industry and Turkish animal husbandry. Their research indicated that the international competitiveness of Turkish plastic sector and marble industry as medium level while Turkish animal husbandry industry's international competitiveness was determined as low level. Riasi (2015) used Porter's diamond model to find out the competitive advantages of shadow banking. According to his findings, government, chance and factor conditions do not contribute to the competitiveness of shadow banking industry. However, firm strategy, structure and rivalry, related and supporting industries, and demand conditions benefit the competitiveness of shadow banking industry. Rodrigus and Khan (2015) employed Porter's diamond model to evaluate the industrial competitiveness of various SAFTA countries and compare the factors contributing to their competitiveness. Gümüş and Hızıroglu (2015) investigated the competitiveness of the selected services in Turkey in comparison with the European Union. Within the scope of their study, Porter's diamond model and three different revealed comparative advantage indices were employed in a combined way. Their findings showed that strong comparative advantages exist for Turkey in tourism, construction and transportation sectors. On the other hand, Turkish insurance and financial and computer-information and communication sectors appear to be weak compared to EU.

Esen and Uyar (2012) discussed whether Diamond Model is an appropriate model to measure the competitive structure of Turkish tourism industry. According to Porter, the diamond model would not be an appropriate model for bequeathed industries of countries (such as climatic characteristics and oil). According to their findings, Porter's Diamond Model explains Turkish tourism industry but it is not sufficient enough. Özer et.al.(2012) identified the differences of Spanish and Turkish tourism industries by using diamond model. According to their findings, Turkey has a positive competitive power as for factor conditions, demand factors, related and support industries, and firm strategy, structure and rivalry. On the other hand, with regards to the chance factor, Turkey does not have a competitive power. Fathi and Ahmadian (2016) examined the competitiveness of the products of Iran Khodro industrial group in international markets, prioritizing factors and suggesting solutions to overcome the present obstacles. They found that the obstacles of exporting the products of Iran Khodro Group are as followed: Chances, government, related and supporting industries, research and development, absorbing, demand conditions, firm strategy, structure and rivalry, factor conditions. Chung (2016) formed assessment criteria of logistics cluster competitiveness using Porter's diamond model, figured out the weight of each criterion by the AHP method, and evaluated logistics cluster competitiveness among Asia main countries. His findings show that there was a significant difference in logistics cluster competitiveness among six countries. Zhao et al. (2009) explored the competitive advantage of Chinese software parks using Porter's diamond model, SWOT framework and interview results. According to their results, the competitive advantages of industry clusters should be strengthened and sustained to enhance industrial development, create innovation and enhance regional economic growth. Park et al. (2009) explored the relative importance of factors that influenced the adoption of air 
express delivery service, and evaluated the competitiveness of air cargo express carriers in the Korean market by employing AHP analysis. Their results showed that accuracy and promptness are the two most influential factors to competitiveness. Yazgan and Yigit (2013) assessed the competitiveness level of the civil aviation industry in Turkey by employing Porter's diamond model. Their analysis revealed that shortage of qualified labor and fuel costs affect the competitiveness level of Turkish Civil Aviation Industry negatively. On the other hand, in terms of high domestic demand, high industry growth and favorable geographical conditions, Turkey has considerable advantages.

\subsection{The Diamond Framework}

Porter argues that a new paradigm is essential in order to understand why a nation is successful in particular industries but not in others. To derive this new analytical framework, which he calls the 'diamond', Porter conducts a study of ten nations. These nations are mostly developed countries: Germany, Sweden, the United States, Denmark, Italy, Switzerland, Japan and United Kingdom, with the exception of Singapore and South Korea, which are seen as newly industrialized countries. Porter states that the home base is critical in that firms tend to build up competitive advantage. He indicates that four attributes of the home environment- namely, demand conditions, factor conditions, firm's strategy, structure and rivalry, and related and supporting industries- play an important role in determining the context which leads domestic firms to gain and sustain competitive advantage. The roles played by the 'government' and 'chance factors" also influence the functioning of these four determinants.

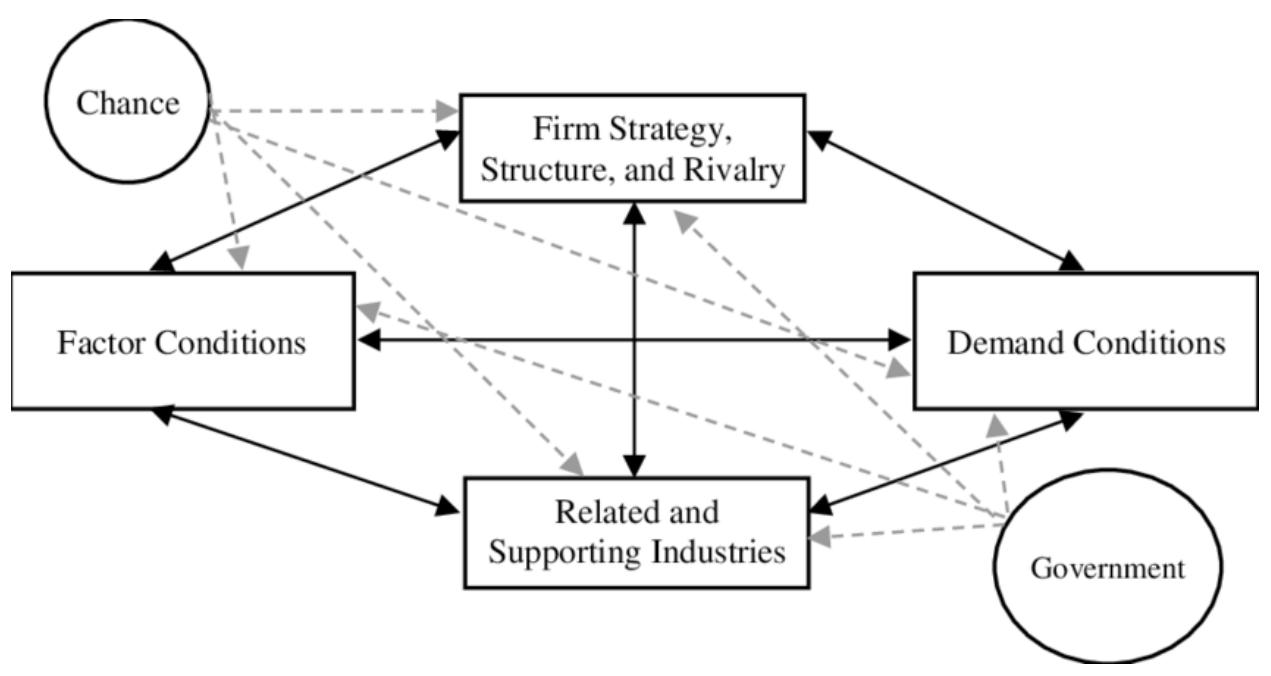

Fig. 1.

The Diamond Framework

Source: (Porter, 1990) 
Figure 1 shows the complete framework Porter offers to capture the sources of competitive advantage in an industry. Michael Porter's diamond model is a useful method to clarify the factors that the company has to take into account in the business operation and the interactions between these factors with a consideration of the external competition, organizational structure and strategic decisions (Zhao et al., 2012; p.362). These attributes will be summarized in the following paragraphs (Porter, 1990).

Factor Conditions. Factor conditions include knowledge resources, raw materials, human resources, capital resources, physical resources, technological resources, infrastructure, manager's capabilities and innovation power. Porter divides factor conditions into two groups: highly specialized resources (e.g. knowledge, technology, and professional human resources) and home-grown resources (e.g. energy, raw material, and unprofessional human resources) (Riasi, 2015; p.18).

Demand Conditions. Porter (1990) suggests that the demand conditions which show the nature of home demand constituted the second broad determinant of national competitive advantage. This determinant is interesting because it relates to the nature of buyers in the home market. Demand conditions are the pressures based on consumers' requirements about services, price and quality in a particular industry. Demand conditions impact the forming of certain factor conditions. They affect the direction and pace of product development and innovation. For example, Japanese car buyers force Japanese car makers with regard to high quality standards requiring them to make the quality of their operations, goods, and activities, which in turn makes ready the industry to compete internationally (Bakan and Dogan, 2012; p.444).

Related and Supporting Industries. The existence of internationally competitive related and supporting industries in a nation contributes to creation and sustainability of competitive advantage. The competitive related industries that share common inputs, skills, technologies, distribution channels or customers may be beneficial for several reasons. Firstly, their similarities may foster technological spillovers. Secondly, a wider dissemination of business information may provide firms to perceive new business opportunities and promote spin-offs. Lastly, threats of new entry from related competitive industries may put the necessary pressure on the existing firms to advance their competitive advantage (Öz, 1999).

Firm Strategy, Structure, and Rivalry. National circumstances and context affect how companies are created, organized, and managed. Competitiveness in a specific industry results from convergence of the management practices and the sources of competitive advantage in the industry. Individual motivation to work and expand skills is also essential to competitive advantage. Outstanding talent is a scarce source in any nation. A nation's success is related to the types of education its talented people choose and their commitment and effort. The presence of strong local rivals is a powerful stimulus to the creation and persistence of competitive advantage (Porter, 1990).

Government and Chance. Porter evaluates the role of government in the competitive development of an industry as an important but indirect one. According to Porter, the proper role for the government should be 
reinforcing the underlying determinants of national advantage apart from trying to create the advantage itself. The chance events are the ones that have little to do with circumstances in a nation and are generally outside the control of firms. Oil shocks, inventions, and wars are examples of chance events. Chance events may allow shifts in competitive position by creating forces that reshape the industry structure (Öz, 1999).

Porter states that each determinant is affected by the others, making the system a dynamic one in which all elements interact with each other. This systemic nature makes it difficult to copy the exact structure of the industry in another country. Therefore, it is essential that the advantage is based on the entire system rather than only one determinant.

\section{Research Method}

The aim of this study is to develop a scale to determine the level of international competitiveness of the airline industry in Turkey. In this study, a competitiveness level scale, validity and reliability study was conducted. The measurement tool developed by the cross-sectional survey model was applied to aviation experts, airline managers and aviation academics. The research was carried out in two basic stages: theoretical and experimental processes. In the theoretical process, a testable theoretical scale form was created and experimental scale form was produced by applying this theoretical measurement form developed in experimental process to target audience. The scale development process is described in detail below.
Measurement Tool Development Process: In this process, the literature (Porter, 1990; Bulu et al., 2006, 2007 and 2008; Erarslan et al., 2007, 2008 and 2009; Rodrigus and Khan, 2015; Park et al., 2009; Gümüş and Hizıroglu, 2015; Yazgan and Yigit, 2013) was examined to form the item pool of the scale. In order to develop the item pool of the measurement instrument, firstly researchers examined studies and measurements tools in the literature.

Content Validity: The content validity study was conducted to evaluate the extent to which each item in the instrument pool developed serves the purpose. All items in the pool have been submitted to the opinions of a manager with many years of experience in the airline industry and an academician who has many studies related to the field of aeronautics for the purpose of testing the content validity. With the suggestions of the participants, new items were added outside the item pool and the theoretical measurement tool was finalized. Thus, a 5 -point Likert-type measurement tool consisting of 36 items was developed. Scale categories are coded as follows; "I do not find it absolutely competitive (1)", "I do not find it competitive (2)", "I find it moderately competitive (3)", "I find it competitive (4)" and "I find it absolutely competitive (5).

Population and Sampling Process: Target population of the study includes aviation experts, airline managers and aviation academics working in Turkey. There is no statistical information available that gives the exact number of the research population. For this reason, it is aimed to reach the number of 180 participants which is at least five times 
the number of items in the measurement tool (36). According to Bryman and Cramer (2001), sample size should be at least five times the number of items in the scale. Simple random sampling method was used in the study. The theoretical measurement form was applied to the employees in the population by means of LinkedIn and applied in online form. The online survey was conducted from 17 to 28 of March 2017.

Construct Validity and Reliability: The data obtained from the scale were first tested with Kaiser-Mayer-Olkin (KMO) and Barlett's sphericity tests in terms of sample suitability and the multidimensional distribution characteristics of the variables. KaiserMeyer-Olkin Measure (KMO) is a measure of sample adequacy. Field (2000) determines the lower limit of the KMO value as .50. The KMO value (.89) calculated for the data is greater than this criterion. This value can be interpreted as the sample consisting of

Table 1

Reliability Analysis before the Exploratory Analysis

\begin{tabular}{|c|c|c|}
\hline & Cronbach's Alfa & N of Items \\
\hline Government & 0.914 & 8 \\
\hline $\begin{array}{c}\text { Firm Strategy, } \\
\text { Structure and Rivalry }\end{array}$ & 0.889 & 7 \\
\hline Demand Conditions & 0.828 & 7 \\
\hline $\begin{array}{c}\text { Related and Support } \\
\text { Industries }\end{array}$ & 0.804 & 6 \\
\hline Factor Conditions & 0.741 & 8 \\
\hline
\end{tabular}

For validity procedures, factor analysis was performed primarily to determine the factors between the items. In the analysis process, the analysis of the basic components was done and finally the varimax rotation process was carried out. Principal component analysis is a widely used method in the literature, although there are different techniques that can be used to reveal factor structures (Klainbaum et al., 1987).

\section{Table 2}

KMO and Barlett Test Values

\begin{tabular}{|c|c|c|}
\hline \multicolumn{2}{|c|}{$\begin{array}{c}\text { Kaiser-Meyer-Olkin Sample } \\
\text { Adequacy }\end{array}$} & $\mathbf{. 8 9 8}$ \\
\hline \multirow{2}{*}{$\begin{array}{c}\text { Bartlett's Test of } \\
\text { Sphericity }\end{array}$} & $\begin{array}{c}\text { Chi-square } \\
\text { Value }\end{array}$ & 2317.901 \\
\cline { 2 - 3 } & $\mathrm{Df}$ & 300 \\
\cline { 2 - 3 } & $\mathrm{p}$ & .000 \\
\hline
\end{tabular}

181 participants is quite sufficient to display factorial structures. The result of Barlett's test was $3531.841(\mathrm{p}<.001)$. The significance of the results of this test indicates that the matrix formed by the relationships between the variables is appropriate and meaningful for factor analysis.

\subsection{Findings}

Table 1 shows the reliability of the scale dimensions before the exploratory factor analysis was executed. The Cronbach alpha values of the scale dimensions range from 0.741 to 0.914 . In the literature, it is stated that Cronbach alpha value should be at least 0.7 for the reliability of the scales (Gürbüz and Şahin, 2014). When the values in the table below are examined, it can be said that the international competitiveness scale of the Turkish airline industry was reliable before the exploratory factor analysis was executed.

In the first factor analysis, no limit was placed on the number of factors, and 8 factors which Eigen values are greater than 1 were determined. The total variance amount explained by the 8 factors is $64.8 \%$. The factors distribution of the items was examined by using the vertical rotation technique and the items with a load value difference of less than .10 for two factors were subtracted from the scale because they showed a tendency to 
cross load. In this phase, the items of 15,11 , $10,29,9,26,4,25$ and 2 were removed from the analysis one by one and the analysis was repeated. Item 1 (.384) was subtracted from the scale as it received a load value lesser than .50. It is stated that the minimum 0.40 load factor is a good criterion for item selection (Nunnally, 1994). Item 7 was removed from the analysis because it constituted a separate factor with the .914 laod value.
Table 2 shows the KMO and Barlett test values after the mentioned items were removed from the analysis.

The value of KMO (.89) indicates that sample size is adequate for the analysis. The significance of Barlett's values $(p<.001)$ supports the hypothesis that data are derived from multivariate normal distribution.

\section{Table 3}

Total Variances Explained

\begin{tabular}{|c|c|c|c|c|c|c|c|c|c|}
\hline \multirow[t]{2}{*}{ Component } & \multicolumn{3}{|c|}{ Initial Eigen Values } & \multicolumn{3}{|c|}{$\begin{array}{c}\text { Extraction Sums of Squared } \\
\text { Loadings }\end{array}$} & \multicolumn{3}{|c|}{$\begin{array}{c}\text { Rotation Sums of Squared } \\
\text { Loadings }\end{array}$} \\
\hline & Total & \begin{tabular}{|c|}
$\%$ of \\
Variance \\
\end{tabular} & Cumulative \% & Total & \begin{tabular}{|c|}
$\%$ of \\
Variance \\
\end{tabular} & Cumulative \% & Total & $\begin{array}{c}\% \text { of } \\
\text { Variance }\end{array}$ & Cumulative \% \\
\hline 1 & 9.032 & 36.130 & 36.130 & 9.032 & 36.130 & 36.130 & 4.654 & 18.615 & 18.615 \\
\hline 2 & 2.516 & 10.062 & 46.192 & 2.516 & 10.062 & 46.192 & 4.150 & 16.600 & 35.215 \\
\hline 3 & 1.646 & 6.586 & 52.778 & 1.646 & 6.586 & 52.778 & 2.414 & 9.657 & 44.872 \\
\hline 4 & 1.350 & 5.399 & 58.178 & 1.350 & 5.399 & 58.178 & 2.412 & 9.649 & 54.521 \\
\hline 5 & 1.199 & 4.795 & 62.973 & 1.199 & 4.795 & 62.973 & 2.113 & 8.452 & 62.973 \\
\hline$\ldots$ & $\ldots$ & $\cdots$ & $\ldots$ & & & & & & \\
\hline 25 & .153 & .614 & 100.000 & & & & & & \\
\hline
\end{tabular}

As seen in Table 3, 5 factors were obtained when Eigen value was taken as 1 and as a result of repeated factor analysis. The total explained variance amount of the five factors is $62.9 \%$. The variance amounts explained by the factors are $36.130 \%$ for the first factor, $10.062 \%$ for the second factor, $6.586 \%$ for the third factor, $5.399 \%$ for the fourth factor and $4.795 \%$ for the fifth factor, respectively. 


\section{Table 4}

Transformed Matrix Components after Factor Analysis

\begin{tabular}{|c|c|c|c|c|c|}
\hline & & & Gactor & & \\
\hline & 1 & 2 & 3 & 4 & 5 \\
\hline Item32 & .783 & & & & \\
\hline Item 33 & .775 & & & & \\
\hline Item 30 & .769 & & & & \\
\hline Item 31 & .768 & & & & \\
\hline Item36 & .747 & & & & \\
\hline Item35 & .739 & & & & \\
\hline Item34 & .726 & & & & \\
\hline Item 21 & & .805 & & & \\
\hline Item 22 & & .748 & & & \\
\hline Item 16 & & .695 & & & \\
\hline Item 20 & & .663 & & & \\
\hline Item 17 & & .653 & & & \\
\hline Item 19 & & .587 & & & \\
\hline Item 18 & & .573 & & & \\
\hline Item 8 & & & .750 & & \\
\hline Item 14 & & & .718 & & \\
\hline Item 13 & & & .652 & & \\
\hline Item 12 & & & .638 & & \\
\hline Item 27 & & & & .743 & \\
\hline Item 24 & & & & .664 & \\
\hline Item 28 & & & & .583 & \\
\hline Item 23 & & & & .533 & \\
\hline Item5 & & & & & .792 \\
\hline Item3 & & & & & .733 \\
\hline Item6 & & & & & .695 \\
\hline
\end{tabular}

When examining the factors distribution of the items by using Varimax vertical rotation method, it was seen that the scale is aggregated in 5 factors which eigen values are greater than 1 and all the items have acceptable load values (the lowest item load value is .53; the highest load value is .80). The sub-dimensions were named taking into consideration the literature. In this context, sub-dimensions are named as Government; Firm Strategy, Structure, and Rivalry; Demand Conditions; Related and Support Industries; and Factor Conditions, respectively.

Table 5

Component and Total Points Correlation

\begin{tabular}{|c|c|c|c|c|c|}
\hline & 1.Factor & 2.Factor & 3.Factor & 4.Factor & 5.Factor \\
\hline 1.Factor & 1 & $.508^{* *}$ & $.362^{* *}$ & $.443^{* *}$ & $.325^{* *}$ \\
\hline 2.Factor & $.508^{* *}$ & 1 & $.481^{* *}$ & $.620^{* *}$ & $.499^{* *}$ \\
\hline 3.Factor & $.362^{* *}$ & $.481^{* *}$ & 1 & $.477^{* *}$ & $.396^{* *}$ \\
\hline 4.Factor & $.443^{* *}$ & $.620^{* *}$ & $.477^{* *}$ & 1 & $.438^{* *}$ \\
\hline 5.Factor & $.325^{* *}$ & $.499^{* *}$ & $.396^{* *}$ & $.438^{* *}$ & 1 \\
\hline
\end{tabular}

**. Correlation is significant at the 0.01 level (2-tailed) 
Pearson Moments Correlation coefficients are calculated as proof of the validity of the scale and the relations of the scale components with each other and the scale total score are presented in Table 5 . When Table 5 is examined, it is observed that the components have a significant positive correlation with each other and the total score in general. These findings are accepted as a demonstration that the scale has a five-factor structure.

\section{Table 6}

Sub-dimensions

\begin{tabular}{|c|c|c|}
\hline Factors & Number of Items & Item Names \\
\hline Government & 7 & $\begin{array}{ll}\text { - } & \text { Airline Policy } \\
\text { - } & \text { Tax Policies } \\
\text { - } & \text { Audit Function } \\
\text { - } & \text { Legislation and Bureaucracy } \\
\text { - } & \text { Incentives } \\
\text { - } & \text { Politic Stability } \\
\text { - } & \text { Stability of Macroeconomic Indicators }\end{array}$ \\
\hline $\begin{array}{c}\text { Firm Strategy, Structure } \\
\text { and Rivalry }\end{array}$ & 7 & $\begin{array}{ll}\text { - } & \text { Airline Management Strategies } \\
\text { - } & \text { Airline Marketing Strategies } \\
\text { - } & \text { Airline Load Factors } \\
\text { - } & \text { Global Market Share of the Airline Industry } \\
\text { - } & \text { Strategic Partnerships } \\
\text { - } & \text { Competition Between Airlines } \\
\text { - } & \text { General Image of Industry }\end{array}$ \\
\hline Demand Conditions & 4 & $\begin{array}{ll}\text { - } & \text { Geographical Location } \\
\text { - } & \text { Domestic Passenger Demand } \\
\text { - } & \text { International Passenger Demand } \\
\text { - } & \text { Transit Passenger Demand } \\
\end{array}$ \\
\hline $\begin{array}{l}\text { Related and Support } \\
\text { Industries }\end{array}$ & 4 & $\begin{array}{ll}\cdot & \text { Airport Industry } \\
\text { - } & \text { Ground Handling Services } \\
\text { - } & \text { Maintenance Organizations } \\
\text { - } & \text { Aviation Educational Institution }\end{array}$ \\
\hline Factor Conditions & 3 & $\begin{array}{ll}\text { - } & \text { Skilled Workforce } \\
\text { - } & \text { Labor Productivity } \\
\text { - } & \text { Information and Technology Infrastructure }\end{array}$ \\
\hline
\end{tabular}

After the validity studies, the reliability analysis of factors and items was performed. Cronbach's Alpha values calculated on the basis of both the content of each sub-dimension and the total are given below.

\section{Table 7}

\section{Reliability Coefficients}

\begin{tabular}{|l|l|}
\hline Factor & Cronbach's Alpha Value \\
\hline Government & .903 \\
\hline Firm Strategy, Structure and Rivalry & .886 \\
\hline Demand Conditions & .748 \\
\hline Related and Support Industries & .733 \\
\hline Factor Conditions & .740 \\
\hline Total & .898 \\
\hline
\end{tabular}


The internal consistency coefficient of the whole scale according to Table 7 is calculated as Cronbach $\alpha=.89$. In addition, the Cronbach Alpha values of the subscales vary between .73 (related and support industries) and .90 (government). These values indicate that the internal consistency of the scale is high.

\subsection{Findings Related to Confirmatory Factor Analysis}

Confirmatory factor analysis was used to test the accuracy of the five-dimensional structure determined by exploratory factor analysis. Table 8 shows fit indices in the literature and values found according to confirmatory factor analysis. As a result of confirmatory factor analysis, it was determined that Chi square/ degree of freedom ratio is 1.401 . A value of $\chi^{2} / \mathrm{df}$ of 3 or below indicates that the model is well fitted. When the RMSEA is examined, it is seen that a fit index of .047 is obtained. The values between 0.01 and 0.06 for RMSEA indicate high compliance ( $\mathrm{Hu}$ and Bentler,1995). In this frame, it can be said that the obtained fit index is perfect. When examining other fit indices, it is seen that GFI is .862 and AGFI is .829. While higher than .95 of GFI and AGFI indices indicate perfect fit between .95 and .90 values show good fit (Çokluk et al., 2014). GFI and AGFI values in the confirmatory factor analysis indicate a poor fit. However, a GFI greater than 0.85 and an AGFI greater than 0.80 are considered acceptable lower bounds for model data fit (Anderson and Gerbing, 1984). The standardized RMR fit index is .062. Under the standardized RMR of .05 indicates perfect fit, under the standardized RMR of .08 shows good fit and under the standardized RMR of .10 indicates poor fit (Çokluk et al., 2014). Standardized RMR value for the analysis indicates a good fit. Finally, when the CFI fit index is examined it is seen that CFI is .951. While greater than .95 CFI index shows perfect fit greater than .90 CFI index indicates good fit (Çokluk et al., 2014). CFI index value for the analysis means perfect fit. In this respect, it can be said that the five-dimensional structure supported by the theory is appropriate.

Table 8

Fit Indices

\begin{tabular}{|c|c|c|c|}
\hline \multirow{2}{*}{ Indexes } & \multicolumn{2}{|c|}{ Threshold Value } & \multirow{2}{*}{$\begin{array}{c}\text { Values of Confirmatory } \\
\text { Factor Analysis }\end{array}$} \\
\cline { 2 - 3 } & Good Fit & Acceptable & 1.401 \\
\hline$\chi^{2} / \mathrm{df}$ & $<3$ & $3<\left(\chi^{2} / \mathrm{df}\right)<5$ & 0.047 \\
\hline RMSEA & $<0.05$ & $<0.08$ & 0.951 \\
\hline CFI & $>0.95$ & $>0.90$ & 0.062 \\
\hline RMR & $<0.05$ & $<0.08$ & 0.862 \\
\hline GFI & $>0.95$ & $>0.90$ & 0.829 \\
\hline AGFI & $>0.95$ & $>0.90$ & \\
\hline
\end{tabular}

Source: Gürbüz and Şahin (2014)

\section{Conclusion}

The exploratory analysis shows that the scale developed to determine the international competitiveness of the airline industry is a valid and reliable measurement tool. Based on the calculated Cronbach Alpha reliability coefficient and the first factor alone, $36.130 \%$ of the variable is explained, it can be said that the scale has a homogeneous structure. The 
components of the scale together account for $62.973 \%$ of the total variance. A fivedimensional structure emerged as a result of exploratory factor analysis based on the Varimax rotation method. These dimensions are government (7 items), firm strategy, structure and rivalry (7 items), demand conditions (4 items), related and support industries (4 items) and factor conditions ( 3 items). It is observed that factor loads vary between .533 and .805 . Taking into account the factor structure and reliability coefficients of the developed scale, the scale can be used as a measurement tool to determine international competitiveness of airline industries.

According to confirmatory factor analysis, RMSEA value of .047, CFI value of .951 and AGFI value of .829 show that the model is close to perfect fit but shows good fit. Furthermore, it can be said that the model is appropriate based on the fact that the result of chi-square/degree of freedom $(366.936 / 262=1.401)$ is less than 5 . In conclusion, findings indicate that the scale can be used to determine international competitiveness of airline industry. This study has provided a valid and reliable measurement tool for determining the level of international competitiveness of the airline industry.

The scale developed in this study can be used determine the countries' international competitiveness power of airline industries. At the macro level, decision-makers can utilize the scale to identify weak points for their airline industry's international competitiveness and take measures to improve them. For future studies, this scale may be applied to different countries and the results may be compared with Turkey. However, it should be noted that since the scale is developed in the context of Turkey, confirmatory factor analysis is required before it is applied to another culture.

\section{Acknowledgement}

This study is supported by the grant of Anadolu University Scientific Research Board, under the project "Analysis of Competitiveness Level of the Turkish Air Transportation Industry", Project No: $1605 \mathrm{E} 232$.

\section{References}

Anderson, J.; Gerbing, W. 1984. The effect of sampling error on convergence, improper solutions, and goodnessof-fit indices for maximum likelihood confirmatory factor analysis, Psychometrika 49: 155-173.

Bakan, I.; Doğan, I. 2012. Competitiveness of the industries based on the Porter's diamond model: An empirical study, IJRRAS 11(3): 441-455.

Bryman, A.; Cramer, D. 2001. Quantitative data analysis with SPSS release 10 for windows. London, Routledge.

Bulu, M.; Erarslan, H.; Barca, M. 2007. Türk gıda sektörünün uluslararası rekabetçilik düzeyinin analizi [In English: Analysis of the level of international competitiveness of the Turkish food industry], Afyon Kocatepe Universitesi, I.I.B.F. Dergisi 9(1): 311-335.

Bulu, M.; Erarslan, H.; Kaya, H. 2006. Türk elektronik sektörünün rekabetçilik analizi [In English: Competitiveness analysis of the Turkish electronics industry], Istanbul Ticaret Universitesi Sosyal Bilimler Dergisi 9: 49-66.

Bulu, M.; Erarslan, H. 2008. Bolu ili turizm sektörünün uluslararası rekabetçilik analizi [In English: Analysis of international competitiveness of Bolu city tourism industry, Seyahat ve Otel İşletmeciliği Dergisi, 1. 
Chung, T. 2016. A study on logistics cluster competitiveness among Asia main countries using the Porter's diamond model, The Asian Journal of Shipping and Logistics 32(4): 257-264.

Çokluk, Ö.; Şekercioğlu, G.; Büyüköztürk, Ş. 2014. Sosyal bilimler için çok değişkenli istatistik: SPSS ve Lisrel uygulamaları [In English: Multivariate statistics for social sciences: SPSS and Lisrel applications], Ankara, Pegem Akademi.

Erarslan, H.; Ipciolu, I.; Hasit, G.; Ersahan, B. 2008. Bilecik bölgesi mermer sektörünün uluslararası rekabetçilik analizi: Sektörel sorunlar ve çözüm önerileri [In English: Analysis of international competitiveness of marble sector in Bilecik region: Sectoral problems and solutions], Mustafa Kemal University Journal of Social Sciences Institute 5(10): 193-217.

Erarslan, H.; Karataş, A.; Kaya, H. 2007. Türk plastik sektörünün rekabetçilik analizi [In English: Competitiveness analysis of the Turkish plastics industry], İstanbul Ticaret Üniversitesi Sosyal Bilimler Dergisi, 11: 203-219.

Esen, S.; Uyar, H. 2012. Examining the competitive structure of Turkish tourism industry in comparison with diamond model, Procedia-Social and Behavioral Sciences 62: 620-627.

Fathi, A.; Ahmadian, S. 2016. Competitiveness of the Iran automotive industry for entrancing into foreign markets, Procedia Economics and Finance 36: 29-41.

Field, A. 2000. Discovering statistics using SPSS for windows, London, Sage Publications.

Gümüş, A.; Hızıroğlu, M. 2015. Measuring and explaining Turkey's competitiveness in services using balassa index and diamond model, Journal of Business Research Turk 7(2): 195-213.
Gürbüz, S.; ve Şahin, F. 2014. Sosyal bilimlerde araştırma yöntemleri: Felsefe-yöntem-analiz [In English: Research methods in social sciences: Philosophy-method-analysis], Seçkin: Ankara.

$\mathrm{Hu}$ L.; ve Bentler, M. 1995. Evaluating model fit. ThousandOaks.Sage.

Klainbaum, G.; Kupper, L.; ve Muller, E. 1987. Applied regression analysis and other multivariable methods, Boston, PWS-Kent Publishing.

Nunnally, J.; ve Bernstein, H. 1994. Psychometric theory, New York, McGraw-Hill.

Öz, O. 1999. The competitive advantage of nations: The case of Turkey. Ashgate.

Özer, K.; Latif, H.; Sarışık, M.; ve Ergün, Ö. 2012. International competitive advantage of Turkish tourism industry: A comperative analyse of Turkey and Spain by using the diamond model of M. Porter, Procedia-Social and Behavioral Sciences 58: 1064-1076.

Park, Y.; Zhang, A. 2009. Evaluating competitiveness of air cargo express services, Transportation Research Part E 45(2): 321-334.

Porter, M. 1990. The competitive advantage of nations, Harvard Business Review March-April: 73-91.

Riasi, A. 2015. Competitive advantages of shadow banking industry: An analysis using Porter diamond model, Business Management and Strategy 6(2): 15-27.

Rodrigues, G.; Khan, R. 2015. Competitiveness of clothing industry based on Porter's diamond model: Safta countries. In Proceedings of Academics World International Conference, USA, 18-23. 
Selli, F.; Erarslan, H.; Chowdhury, D.; Sukumar, A. 2010. International competitiveness: analysis of Turkish animal husbandry: An emprical study in gap region, Enterprise Risk Management 1(1): 100-114.

Yazgan, A.; Yigit, S. 2013. Türk sivil havacılık sektörünün uluslararası rekabetçilik düzeyinin analizi [In English: Analysis of the level of international competitiveness of the Turkish civil aviation industry], The Journal of Social and Economic Research 25: 421-445.
Zhao, W.; Watanabe, C.; Griffy-Brown, C. 2009. Competitive advantage in an industry cluster: The case of Dalian software park in China, Technology in Society 31: 139-149.

Zhao, Z.; Zuo, J.; Zillante, G.; Zhao, X. 2012. Foreign architectural and engineering design firms' competitiveness and strategies in China: A diamond model study, Habitat International 36: 362-370. 